Pamiętnik Literacki 2015, 1, s. 129-146

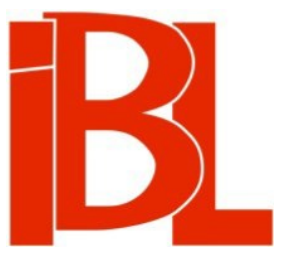

\title{
„Bogurodzica”: struktura czasoprzestrzeni i obraz poetycki
}

Krzysztof Obremski 


\title{
Z A G A D N I N I A J E Z Y K A A R T Y T T C Z N E G O
}

Pamiętnik Literacki CVI, 2015, z. 1, PL ISSN 0031-0514

KRZYSZTOF OBREMSKI Uniwersytet Mikołaja Kopernika, Toruń

\section{„BOGURODZICA”: STRUKTURA CZASOPRZESTRZENI I OBRAZ POETYCKI}

\begin{abstract}
Należy wpierw rozważyć myśl〈sententia〉, zanim zajmiemy się łączeniem słów $\langle v e r b a\rangle$. Słowa bowiem są martwe, jeśli w całości nie rozświetli ich myśl, która w pewien sposób jest duszą słowa. Gdy myśl się ukształtuje, należy przejść do słów, dołożywszy starań, aby ich ciąg był ozdobny. [Godfryd $\mathrm{z}$ Vinsauf]

Poeta wie, że mógł napisać inaczej - dla czytelnika w tekście odbieranym jako artystycznie doskonały nie ma nic przypadkowego. [Jurij Łotman] $]^{1}$
\end{abstract}

Jako autor/podmiot literaturoznawczy daleki jestem od tego, co bywa nazywane topiką afektowanej skromności (niekiedy także fałszywej), jednak na początku powinienem przedstawić trzy „samoponiżające” wyjaśnienia.

„Struktura” - poprzestaję jedynie na tym, co najogólniejsze w strukturalistycznym stylu myślenia:

własności rzeczy nie są uznawane za immanentne, lecz za relacyjne: „natura” zjawisk leży nie w nich samych, lecz w ich wzajemnych związkach. I podobnie, odkrywane w obiekcie znaczenie zależy tyleż od układu jego części, co od powiązań z innymi obiektami oraz pozycji zajmowanej w ramach całości rekonstruowanego systemu odniesienia ${ }^{2}$.

Samoistna i $z$ trudem porównywalna $z$ innymi pieśniami archaiczna część Bogurodzicy jako średniowieczna sztuka słowa sprzyja temu, aby (przynajmniej tu i teraz) poniechać analizy porównującej z „innymi obiektami”, pamiętając jednakże o tym, że „dla człowieka, który chciałby mieć do czynienia z tekstem wyrwanym $z$ całości związków zewnątrztekstowych, dzieło w ogóle nie mogłoby być nośnikiem żadnych znaczeń”3. Tak więc analiza Bogurodzicy w kontekście np. śred-

1 Godfryd z Vinsa uf, Documentum de modo et arte dictandi et versificandi (Wykład o sposobie i sztuce pisania proza i wierszem). Przeł. T. Sz o s t e k. W zb.: Źródła wiedzy teoretycznoliterackiej w dawnej Polsce. Średniowiecze - renesans - barok. Wstęp, wybór, oprac. M. Cy t ow s ka, T. M i chałowska. Warszawa 1999, s. 152. - J. Łotman, Struktura tekstu artystycznego. Przeł. A. Tan als ka. Warszawa 1984, s. 45.

2 R. Ny c z, Strukturalizm, teoria literatury i Edwarda Stankiewicza koncepcja poetyki. W: E. S t a nki ew i c z, Poetyka i sztuka słowa. Red. nauk. R. Ny c z, W. W a le cki. Kraków 1996, s. 8.

3 Łotman, op. cit., s. 74. I dalej (s. 76): „Tekst artystyczny [...] jest zawsze elementem bardziej złożonej konstrukcji zewnątrztekstowej i tworzy z nią opozycję binarną". 
niowiecznej wiedzy teoretycznoliterackiej pozostaje jednym $\mathrm{z}$ wyzwań doprawdy nieuniknionych ${ }^{4}$.

„C z a s o p r z e s tr z e ń” - problematyki zwerbalizowanej tym terminem niepodobna wyczerpać, na co tylko bardzo pośrednio wskazuje fakt następujący: wydana w r. 2012 książka Henryka Nadrowskiego Sacrum czasoprzestrzeni. Reinterpretacje - kontrowersje - świat wartości liczy ponad 800 stronic.

"Obraz poety cki” - ten, co prawda, mógłby stać się przedmiotem analizy teoretycznoliterackiej, jednak jako fakt historyczny (tj. przeżycie osób śpiewających Bogurodzicę w jej średniowiecznym kontekście kulturowym) może być co najwyżej interpretacyjną hipotezą: skoro sama pieśń ojczysta jawi się jako materia zapewne już nierozstrzygalnych problemów, tym trudniej mówić nam o jej ówczesnym poetyckim przeżywaniu ${ }^{5}$. Zarazem nie miejsce tu, by jakkolwiek podjąc pytanie o ewolucję współczesnego statusu Bogurodzicy wraz z postępującą sekularyzacją Polski.

Wbrew tym trzem zastrzeżeniom trudno opierać się wyzwaniu, jakim - mimo kilkunastu dziesięcioleci intensywnych prac i jakże licznych publikacji 6 - Bogurodzica wciąż pozostaje.

Subiektywnie postrzegany stan badań nad pieśnią ojczystą może wydawać się bezkresny, toteż nawet niepodobna zasygnalizować tego wszystkiego, co powinno być przywoływane w jakiejkolwiek pracy poświęconej Bogurodzicy czytanej jako poetyckie arcydzieło średniowiecznej pobożności. Absolutnie pełne zdanie sprawy z zadłużenia niniejszego tekstu we wcześniejszych publikacjach oznaczałoby nie

Zob. T. Mich hłow ska, Średniowieczna teoria literatury $w$ Polsce. Rekonesans. Wrocław 2007, passim.

5 Zob. A. C zyż, „Bogurodzica” - między Wschodem a Zachodem. Kilka myśli o duchowej jedności Europy. W: Światto i słowo. Egzystencjalne czytanie tekstów dawnych. Warszawa 1995, s. 3 (podkreśl. K. O.): „Była bowiem [Bogurodzica] śpiewem ojców, pieśnią przodków, wpisaną w duchowe dzieje narodu, a egzystencję przeszłą unaoczniała: jako wizja, obraz, gło s".

6 Ten stan „uczonej niewiedzy” mogą - przykładowo - przybliżyć słowa T. M i c hałow s ki ej (Średniowiecze. Warszawa 1995, s. 278-281):

„Nie znamy pierwotnego, oryginalnego tekstu Bogurodzicy i nie wiemy, jak brzmiał on w momencie swych literackich narodzin. Nie umiemy określić czasu i miejsca powstania pieśni, ani, tym bardziej, wskazać twórcy jej słów i melodii. Domyślamy się, że żyjący (jak długo?) w ustnym przekazie utwór, zgodnie z prawidłami poezji oralnej, ulegał zmianom i przekształceniom, zanim jego dwie, różniące się między sobą, wersje zostały utrwalone w piśmie na początku XV wieku.

$[\ldots]$

Można bez wielkiej przesady powiedzieć, że kryje się w nim [tj. w tekście Bogurodzicy] więcej zagadek i niejasności, niż jesteśmy w stanie postrzec to "gołym okiem", od najgłębszych treści teologicznych po segmentację ciągu następujących po sobie wyrazów (na wersy, zdania i ich człony) czy wreszcie - po znaczenia, a nawet pisownię pojedynczych słów”. Zob. też s. 291.

I jeszcze jeden cytat - ponownie wyłącznie przykładowo, by wskazać zakres „uczonej niewiedzy” - z pracy P. Ko cikow s ki e go Dwie pierwsze zwrotki „Bogurodzicy” dwoma odrębnymi utwora$m i$ (,Zeszyty Naukowe Uniwersytetu Mikołaja Kopernika w Toruniu. Nauki Humanistyczno-Społeczne” z. 12. Filologia Polska, z. $5\langle 1965\rangle$, s. 69):

„W nauce polskiej utarł się zwyczaj ujmowania dwu pierwszych zwrotek Bogurodzicy jako zamkniętą w sobie, nierozerwalną całość, a zarazem jako pierwotny zrąb najstarszej pieśni polskiej. [...] Obóz przeciwników jednolitości obu pierwszych zwrotek jest również dość liczny”.

Potwierdzenie wyjątkowego statusu literaturoznawczego Bogurodzicy stanowi poświęcony jej zeszyt „Pamiętnika Literackiego” (2005, z. 2). 
tylko opatrzenie go jeszcze liczniejszymi przypisami - co gorsza: ogromna mozaika odwołań i cytatów przesłoniłaby to, co w nim oryginalne. Poprzestanę zatem na wskazaniu pracy, która jest moją bezpośrednią inspiracją: to artykuł Zdzisławy Krążyńskiej i Tomasza Miki Architektura „Bogurodzicy”. Ten tekst skłonił mnie do sformułowania niniejszej interpretacji alternatywnej, gdyż pewnej tezy jego autorów nie podzielam: podziw dla nich łączę $\mathrm{z}$ odmiennym postrzeganiem struktury czasoprzestrzeni zwerbalizowanej w pieśni. Moje odrębne zdanie najogólniej wiąże się z tym ich twierdzeniem:

Metafizyczna przestrzeń wykreowana w utworze jest w każdym wymiarze dwuwarstwowa, a ponadto zhierarchizowana. Tworza ją przede wszystkim osoby (boskie i ludzkie) i relacje między nimi, wypełniają zaś działania osób. [...]

Tak jak modlitwa oplatała przestrzeń, tak też przenikają się obie przestrzenie: wyższa [tj. boska] s chodzi do niższej [tj. ludzkiej], niższa wznosi się ku górze, zarazem odbijając się w wyższej, ale także ją współtworząc, co sprawia, że obie w gruncie rzeczy są nierozdzielne ${ }^{7}$.

W tych zdaniach znajduję najogólniej ujęte dwie społeczności: „osoby (boskie i ludzkie)". Te pierwsze to Jezus Chrystus (w którym Bóg stał się człowiekiem), Maria (która trzykrotnie przekroczyła ludzką nature - niepokalanie poczęta Dziewica urodziła Boga) i Jan Chrzciciel (pierwszy człowiek, który oddał cześć Zbawicielowi). Osoby ludzkie pozostają, przynajmniej potencjalnie, wewnętrznie zróżnicowane (tzn. pośmiertnie zbawieni lub potępieni), dlatego zamiast o ich „wspólnocie” może lepiej mówić o „społeczności”.

Jak niepodobna zaprzeczyć średniowiecznej antropomorfizacji zaświatów, tak też Bóg Jezus Chrystus i ludzka Matka Boga jako postacie świata przedstawionego słowami Bogurodzicy nie pozwalaja mówić o zniżaniu się świata Boskiego i wznoszeniu się świata ludzkiego. Wcielenie i Zmartwychwstanie, Niepokalane Poczęcie oraz Wniebowzięcie maja, co prawda, fundamentalne znaczenie dla wszystkich ludzi (pośrednio nawet dla pogan - formuła „anima naturaliter christiana”), jednak pozostają wydarzeniami jednostkowymi. Współtworzą one jakby dwie drogi bezpośredniego połączenia społeczności Boskiej i społeczności ludzkiej, dane tylko dwóm osobom: Zbawicielowi i Matce. W Jezusie Chrystusie Bóg w Trójcy Jedyny $^{8}$ stał się człowiekiem - natomiast żaden chrześcijanin, nawet za sprawa ofiary złożonej na krzyżu i zmartwychwstania, nie stał się jakimkolwiek bogiem czy półbogiem. Zbawiciel miał ludzkie ciało, to jednak nie znaczy, że tym samym ludzka natura stała się częścią natury Boskiej. Jeśli przyjmiemy, iż w Synu Bożym te dwa światy (Boski i ludzki) współtworzą jednię, wówczas owe dwa przeciwne ruchy jednej i drugiej przestrzeni (tj. ludzkiej i Boskiej) przeczyłyby tak średniowiecznej teologii (vide drabina bytów, gdzie człowiek, co prawda, jest rozdwojony - ciałem należy do bytów materialnych, duszą z kolei do bytów duchowych - ale nieruchomo

7 Z. Krążyń s ka, T. Mika, Architektura „Bogurodzicy”. „Slavia Occidentalis” t. 52 (1995), s. 51. Podkreśl. K. O. Dalej trzykrotnie znajdziemy „świat boski obniżony” (s. 53). O kształtach trzech modlitewnych kręgów - zob. s. 61.

8 Zob. drzeworyt Tajemnica Trójcy wyrażona w trójkacie mistycznym (Paryż 1524). W: S. Ko bi i lu s, Człowiek i ogród rajski $w$ kulturze religijnej średniowiecza. Warszawa 1997, il. czarno-biała nr 9. Najkrótsze wyjaśnienie trójkąta mistycznego brzmi: „Owocem tak wielkiej nobilitacji geometrii w średniowieczu były próby geometryzacji definicji samego Boga” (ibidem, s. 30). 
pozostaje usytuowany między zwierzętami i aniołami), jak też temu aksjomatowi średniowiecznej kultury, za jaki jest uważana hierarchiczność. Syn Boży poj ed y n c zo stał się człowiekiem - Maria jako niepokalanie poczęta i dziewicza Matka Boża p oj e dy n c z o przekroczyła ludzką naturę. Wcielenie i Niepokalane Poczęcie nie pozwalają mówić o s chodzeniu całego świata Boskiego, Wniebowstapienie Jezusa Chrystusa i Wniebowzięcie Marii - o wznoszeniu się całego świata ludzkiego. Twierdzenie „Tak jak modlitwa oplatała przestrzeń, tak też przenikają się obie przestrzenie" jest trafne tylko w ograniczonym zakresie: przestrzeń Boska faktycznie przenika ludzką (psalmowe „Niebiosa opowiadają chwałę Boga”; świat jako przestrzeń działania Bożej Opatrzności; człowiek jako teologicznie tajemniczy splot Bożej łaski i często grzesznej wolnej woli), ale powiedzieć, że świat ludzki przenika świat Boski można tylko pod warunkiem uprzedniego przyjęcia ateistycznej czy tylko antropologicznej optyki: to człowiek stworzył Boga i zaświaty. Jednak w kontekście historycznym Bogurodzicy ateizm byłby wręcz niedorzeczny, a średniowieczna antropologia powinna pozostać (jak ówczesna filozofia) podporządkowana teologii.

Twierdzenie o schodzeniu przestrzeni Boskiej do ludzkiej i wznoszeniu się ludzkiej do Boskiej swój historycznie silniej uzasadniony kontekst znajdzie nawet nie tyle w kulturze sarmackiej ${ }^{9}$, ile przede wszystkim dopiero w pierwszym od czasów soboru trydenckiego Katechizmie Kościoła katolickiego z jego tytułem początkowego rozdziału Człowiek jest „otwarty” na Boga (capax Dei), co przez Józefa Tischnera będzie pojmowane jako „nowa mechanika religii” ${ }^{10}$. Tymczasem, tj. w średniowiecznym kontekście Bogurodzicy, można mówić jedynie o takich dwóch przeciwnych ruchach: pobożnych podążających ku zbawieniu (tj. niebu - łącznie $\mathrm{z}$ prowadzącym do niego czyśćcem ${ }^{11}$ ) oraz grzeszników zmierzających w stronę piekła. Sam Bóg pozostaje nieporuszony (św. Tomasz - dowód z ruchu), a człowiecze drogi życia i związane z nimi siły zbliżania się „do” Boga czy też oddalania się „od” Niego pozostają niezgłębione jako docześnie tajemny splot Bożej łaski, ludzkiej

9 Zob. badania J. Tazbir a nad sarmatyzacją katolicyzmu - tu np. jego praca Sarmatyzacja potrydenckiego katolicyzmu (w: Szlachta i teologowie. Studia z dziejów polskiej kontrreformacji. Warszawa 1987).

10 Zob. J. Tis chner, J. Żakows ki, Tischner czyta Katechizm. Kraków 1996, s. 12-13:

„W pewnym sensie okaże się, że dla Boga centrum świata jest człowiek. Natomiast dla człowieka centrum świata jest Bóg. Używając metafory kopernikańskiej, można rzec, że Ziemia się kręci, ale Słońce też się kręci. "Capax Dei« oznacza, że mamy zarówno ruch człowieka wokół Pana Boga, jak i ruch Boga wokół człowieka.

$[\ldots]$

[...] Można więc powiedzieć: ten nowy Katechizm będzie pokazywał dwojaki ruch w świecie naszych wartości. Ruch, w którym Bóg siebie uczłowiecza, a człowiek się ubóstwia.

$[\ldots]$

Wyraźnie natomiast widać, że ten katechizm szuka takiego miejsca w Bogu, które jest najbardziej ludzkie, i takiego miejsca w człowieku, które jest najbardziej boskie”.

11 Wiek XII był czasem narodzin czyśćca. Według XIII-wiecznej glosy do Sentencji Piotra Lombarda dusze oczekujące nieba są charakteryzowane dwoma komponentami: „Niektórzy [zmarli] są średnio dobrzy i dzięki wstawiennictwom mogą dostapić zupełnego rozgrzeszenia; ci bez wątpienia przebywają w czyśćcu”. Cyt. za: J. Le G off, Narodziny czyśćca. Przeł. K. Ko cja n. Posł. Z. Mik ołej k o. Warszawa 1997, s. 226. 
wolności, wstawiennictwa świętych pośredników (szczególnie Marii oraz Jana Chrzciciela), jak też sił piekielnych.

\section{Przekaz kcyński: jedna struktura czasoprzestrzeni czy pięć?}

W zmierzaniu się $\mathrm{z}$ wyzwaniem, jakim wciąż pozostaje Bogurodzica, wybór jednego z dwóch najstarszych przekazów (kcyńskiego lub krakowskiego) nie oznacza bynajmniej, że struktura czasoprzestrzeni Bogurodzicy niejako automatycznie zyskuje stabilną podstawę tekstową, ponieważ każdy z nich może otrzymać różne zapisy $\mathrm{w}$ odmiennych formach metrycznych. Unaoczniaja to kolejne edycje przekazu kcyńskiego ukazujące się w drugiej połowie XX w. (wymieniam je w porządku chronologicznym):

- według Jerzego Woronczaka „Pierwsze dwie zwrotki pieśni to trop, a właściwie dwa tropy”; jednak dwie zwrotki zostały „przepołowione” (tzn. podzielone na semiversiculi), tak że graficzny zapis dwóch strof jest obrazem czterech strof ${ }^{12}$;

- Julian Krzyżanowski „dwuzwrotkowy hymn” przedstawił jako wiersz liczący trzy graficznie wyodrębnione strofy ${ }^{13}$;

- Ewa Ostrowska na początku studium poświęconego Bogurodzicy przyjęła tekst podzielony na trzy strofy ${ }^{14}$ (przedstawione w tej samej postaci, jaką nadał im Krzyżanowski);

- jako autor Średniowiecznej pieśni religijnej polskiej Mirosław Korolko wybrał zapis dwustrofowy ${ }^{15}$ (jednak odmienny od przyjętego przez Woronczaka);

- autorzy Chrestomatii staropolskiej opowiedzieli się za tym, że przekaz kcyński jest współtworzony przez cztery strofy ${ }^{16}$ (ale doprawdy nieporównywalne $z$ tymi wyróżnionymi przez Woronczaka);

- w Średniowieczu Teresy Michałowskiej wpierw mamy liczacy trzy strofy zapis tekstu Bogurodzicy (podział taki, jaki został przyjęty przez Krzyżanowskiego i Ostrowska), lecz kilka stronic dalej znajdziemy podział na dwie strofy, przy czym te sa podzielone na semiversiculi: policzone wzrokiem widnieja przed oczami w liczbie siedmiu ${ }^{17}$ (wyróżnione semiversiculi są jednak inne niż przyjęte przez Woronczaka).

Tak więc przychodzi stwierdzić, że graficzny zapis przekazu kcyńskiego liczy od dwóch do siedmiu wielorako wyróżnianych strof pojmowanych jako jednostki postrzegane naocznie. Jeśli linearny porządek słów determinuje wyobrażenia nimi ewokowane (co szczególnie w tekście tak skondensowanym jak Bogurodzica nie powinno wywoływać wątpliwości), to wybór graficznego zapisu przekazu kcyńskie-

Bogurodzica. Oprac. J. W or on czak. Wstęp językoznawczy E. Ostrowska. Oprac. muzykologiczne H. Feight. Wrocław 1962, s. 80.

J. Kr zy ż a n ow s k i, Historia literatury polskiej. Alegoryzm - preromantyzm. Warszawa 1966, s. 54.

E. O s trow s ka, „Bogurodzica”. W: O artyzmie polskich średniowiecznych zabytków językowych („Bogurodzica”, „Kazania świętokrzyskie”, „Posłuchajcie, bracia miła”). „Zeszyty Naukowe Uniwersytetu Jagiellońskiego” nr 154. „Prace Językoznawcze” z. 20 (1967), s. 7.

15 Średniowieczna pieśń religijna polska. Oprac. M. Ko rolko. Wrocław 1980, s. 4.

16 W. Wydra, W. R. Rze pka, Chrestomatia staropolska. Teksty do roku 1543. Wrocław 1984, s. 235.

17 Michałowska, Średniowiecze, s. 281, 289. 
go czy też krakowskiego określa świat przedstawiony z jego strukturą czasoprzestrzeni. Dlatego dla przekazu kcyńskiego należy wyróżnić przynajmniej pięć czasoprzestrzennych struktur. Nie miejsce tu na jakiekolwiek pogłębione porównywanie poszczególnych zapisów tego przekazu, toteż poprzestaje jedynie na zasygnalizowaniu problemu, który dla struktury czasoprzestrzeni Bogurodzicy jest wręcz węzłowy. Innymi słowy: przekaz kcyński pozwala mówić o przynajmniej pięciu owych strukturach, ponieważ można wskazać akurat tyle zapisów graficznych. Takie równanie liczb (pięć i pięć) jest uwarunkowane tym, że wierszowe „obrazy” przekazu kcyńskiego determinują różne rytmy oraz rymy, one zaś są jednymi z najistotniejszych elementów wiersza. Już Izydor z Sewilli, „którego Etymologie oddziaływały trwale na autorów XIII-XV w.”, pisał: „Pieśnią nazywa się to, co jest ujęte w miary metryczne"18. Toteż odmienne podziały stroficzne Bogurodzicy, sprzężone zwrotnie $\mathrm{z}$ różnymi metrami i rymami, wielorako kształtują jej samoistne kompozycje, a wraz z nimi światy przedstawione, w tym struktury czasoprzestrzeni.

Analogiczny argument na poparcie twierdzenia, że pięć zapisów graficznych przekazu kcyńskiego to w istocie wierszowej rzeczy pięć różnych struktur czasoprzestrzeni, można wywodzić z tej definicji wiersza, jaką Mateusz z Vendôme rozpoczął swą Ars versificatoria: „Wiersz jest mową metryczną o przebiegu ograniczonym i zamkniętym, malowniczą dzięki przyjemnemu związkowi słów i kwieciu myśli, nie zawierającą w sobie niczego ułomnego ani zbędnego"19. Tak więc można mówić o proporcji: ile stroficznych podziałów „ograniczonej i zamkniętej” Bogurodzicy z ich „mowami metrycznymi”, tyleż wierszy opatrzonych tytułem Bogurodzica - z samoistnymi kompozycjami i z nimi splecionymi strukturami czasoprzestrzeni. Mówiąc nieco inaczej: ile wariantów stroficznych zapisu graficznego liczy przekaz kcyński, tyle należy wyróżnić struktur czasoprzestrzeni - ponieważ każdy z owych zapisów będzie poniekąd samoistnym „sprowadzeniem dynamicznego dźwięku do bezdźwięcznej przestrzeni” ${ }^{20}$. Także w kontekście Bogurodzicy pismo, jako „Słowo poddane technologii" (tak wymownie brzmi podtytuł książki Waltera Jacksona Onga Oralność i piśmiennośc), pozostawało takim medium, którego przecenić niepodobna: „przejście od mowy oralnej do [wypowiedzi] pisanej to w zasadzie przejście od dźwięku do przestrzeni widzianej”21. Do pięciu „przestrzeni widzianych” należą determinujące strukturę czasoprzestrzeni - zróżnicowane zapisy graficzne kcyńskiego przekazu Bogurodzicy.

Zważywszy na tekstową „polimorficzność”22 czy edytorską „wariantywność”

19 Cyt. jw., s. 91 (przeł. E. Sarnowska-Temeriusz).

20 W. J. O n g, Oralność i piśmienność. Stowo poddane technologii. Przekł., wstęp J. J a po la. Lublin 1992, s. 117.

21 Ibidem, s. 160. Dopowiedzenie opatrzone nawiasem kwadratowym jest konieczne: podobnie jak nie istnieje „literatura oralna” (ibidem, s. 31-37), tak też nie ma „mowy pisanej”.

22 Przedstawiając „różnice między epokami wcześniejszymi a epoką nowożytną” A. Dą b rówka (Konstruktywizm $w$ badaniach literatury dawnej. „Nauka” 2009, nr 3, s. 141) pisze: „Na etapie publicznego istnienia tekstu im bardziej się cofamy w historii kultury, tym "tekstu" coraz bardziej nie ma, i nie chodzi tu o liczbę zachowanych przekazów, tylko o coraz bardziej rozproszone istnienie dawnych tekstów, dla których zapis jest tylko jedną z wielu form istnienia”. 
przekazu kcyńskiego ${ }^{23}$, trudno nie sformułować pytania: który jego zapis powinien stać się podstawą tekstową rozpoznawania struktury czasoprzestrzeni Bogurodzicy? Odpowiedź może mieć znaczenie wręcz fundamentalne ${ }^{24}$. Jednocześnie jesteśmy poniekąd zmuszeni zmierzyć się $z$ istotną kwestią teorii dzieła literackiego, ponieważ o czasoprzestrzeni zarazem można twierdzić, że wobec słów tekstu pozostaje względnie samoistnym dziełem wyobraźni (byłaby sumą zhierarchizowanych elementów?), jak też uznać, że sprzężenie zwrotne między res a verba ma wręcz totalny zakres i władza słów nad wyobrażeniami pozostaje bezwzględnym dyktatem.

Innymi słowy, „polimorficzność” czy „wariantywność” przekazu kcyńskiego może nawet wymusza dokonanie podstawowego wyboru: przyjąć jako werbalną podstawę struktury czasoprzestrzeni jeden spośród pięciu zapisów przekazu kcyńskiego czy niejako wznieść się ponad ich wierszowe zróżnicowanie i ws zy stki e przekazy ogarnać jednym ogólnym spojrzeniem? W moim przekonaniu to drugie rozwiązanie wydaje się trafniejsze dla poznania struktury czasoprzestrzeni Bogurodzicy, a zatem świata konstruowanego postaciami oraz ich statusami i działaniami w dwojakich relacjach: przestrzennych i czasowych.

Tak więc, zważywszy na „wariantywność” przekazu kcyńskiego, nie podejmuję pytania o to, która $z$ pięciu postaci zapisu jest tu przyjęta jako determinanta czasoprzestrzeni Bogurodzicy, ponieważ owa czasoprzestrzeń nie wydaje się zdeterminowana liczbami strof ani ich metrycznymi formami ${ }^{25}$. To wszak Boskie i ludzkie osoby w ich teologicznych statusach oraz działaniach fundamentalnie kształtuja strukturę czasoprzestrzeni Bogurodzicy ${ }^{26}$, nie zaś linearne porządki słów i zespo-

Zob. Krążyń ska, Mi ka, op. cit., s. 47: „Podnosi się mianowicie drobioną budowę utworu, polegającą na tworzeniu większych, złożonych całostek, $\mathrm{z}$ mniejszych. Wyodrębniono w związku z tym trzy ich poziomy: człony, wiersze i tzw. periody. Człony tworzą wiersze, z wierszy zaś powstają periody. Całość skomponowana jest z dwóch periodów, z których pierwszy ma dwa wiersze trójczłonowe (lub czteroczłonowe) i jeden dwuczłonowy, a period drugi dwa wiersze trójczłonowe i cztery dwuczłonowe. Wiersze krótkie są zawsze dwuczłonowe”.

Z jednej strony, niepodobna podważać dawnych związków poezji i retoryki, z drugiej jednak - takie „przeniesienie” Bogurodzicy z poetyki do teorii retorycznej należy uznać za dyskusyjne, ponieważ (niezależnie od przekazów oraz ich zapisów) charakteryzuje tę pieśń wyjątkowa zwięzłość, w sztuce zaś wymowy periody czy tym bardziej okresy nie charakteryzowały się zwartością. Wręcz przeciwnie. Zob. K. Gó r s ki, Jakub Wujek jako pisarz. W: Z historii i teorii literatury. Wrocław 1959, s. 72 .

24 Zob. Krążyńs ka, Mi ka, op. cit., s. 56: „Okazuje się [...], że układ linearny tekstu jest niezwykle znaczący i dlatego analizując kolejne całostki, trzeba wydobywać dodatkowe sensy będące pochodną kolejności słów w tekście”.

Zob. ibidem, s. 51:

„Już choćby określenie Bogurodzicy jako pieśni-modlitwy to uchwycenie tylko jednego jej aspektu, bo równolegle rozwija się teologiczny wykład ustanawiający ze względu na modlitwę metafizyczną przestrzeń, w której się ona dokonuje. Kształtowanie przestrzeni odbywa się przez przypominanie podstawowych prawd teologicznych, które są wszakże realizowane właśnie w modlitwie.

Jest zatem tak, jakby teologiczną osnowę przeplatał modlitewny wątek, to znikając pod nią, to znów wydostając się na powierzchnię, lub, innymi słowy, jakby modlitwa oplatała metafizyczną przestrzeń. [...]”.

26 Zob. ibidem (podkreśl. K. O.): „Poza osobami i ich aktywnością jest jeszcze tylko świat jako miejsce pobytu ludzi i pośrednio przywołany raj, określający warunki, lecz nie miejsce przebytu ludzi. Przy czym świat, widziany z perspektywy ludzkiej jako miejsce, w istocie jest jednak nie miejscem, ale by te m”. 
lone $\mathrm{z}$ ich następstwami odmienne postacie stroficzne. Wszystkie one - osoby, statusy oraz działania - najgłębiej są związane $z$ chrześcijańskim pojmowaniem czasoprzestrzeni ${ }^{27}$.

\section{Czasoprzestrzeń}

\section{Pół wieku temu Ewa Ostrowska napisała:}

Język pieśni jest zwięzły i ścisły. I co ważne: widocznie funkcyjny. [...]

$[\ldots]$

W sumie mamy do czynienia zapewne $\mathrm{z}$ cechą stylową, wymagającą zwięzłości i oszczędności słowa, rozumienia toku językowego w ścisłym związku z kontekstem, a może nawet przer zu cania ostatecznych sensów na kontekst ${ }^{28}$.

Cóż współtworzy ów kontekst? Na tak sformułowane pytanie nie ma odpowiedzi definitywnej. Toteż poprzestanę na tym, co zarazem najbliższe Bogurodzicy i najistotniejsze: owe „ostateczne sensy” są współtworzone tak przez religijny mikrokosmos pieśni, jak też przez makrokosmos ${ }^{29}$ - jest nim średniowieczny obraz świata i zaświatów $z$ ówczesnym pojmowaniem czasoprzestrzeni.

Postaciami werbalnie wskazanymi w tekście są: Maria, Bożyc (z nim zaś Bóg w Trójcy Świętej - wszak od niej abstrahować niepodobna ${ }^{30}$ ), społeczność grzeszników (modlitewne „my”), Chrzciciel, zbawieni chrześcijanie. Wraz z tymi postaciami, jako ich najbliższy kontekst (zgodnie z kompozycją Bogurodzicy, którą charakteryzują przeciwieństwo, kontrast oraz formy równoległe ${ }^{31}$; zarazem - „Schemat

Nie stawiam tu pytania o zasadność takiego interpretacyjnego przejścia od „pobytu” i „przebytu” do „bytu”: jak niepodobna kwestionować średniowiecznego splotu wiary chrześcijańskiej i filozofii, tak tajemniczość Bogurodzicy, również ta związana ze znaczeniami jej słów, skłania do ostrożności i (tym samym?) do powstrzymania się przed filozoficznym rozumieniem słów „pobyt” i „przebyt”. Znamienne, że chociaż w dziele J. D el u m e a u Historia raju. Ogród rozkoszy (Przeł. E. B ą k o ws ka. Warszawa 1996) znajdziemy podrozdział Doskonałość bytu, to przecież zostaje w nim podjęte jedynie pytanie o doskonałość postaci Adama i Ewy w kontekście idyllicznych warunków życia w biblijnym wieku złotym. Inny argument przemawiający przeciwko pojmowaniu „rajskiego przebytu" jako bytu (nie zaś jako miejsca) wiąże się z genezą Bogurodzicy: prymarnie oralny status utworu (nie wiadomo, jak długo pozostającego w jedynie ustnym przekazie) raczej nie sprzyjał ufilozoficznieniu modlitwy.

27 Zob. Krążyńska, Mika, op. cit., s. 51-55:

„Początek pieśni jest swoistym komentarzem skutków nieobecnego bezpośrednio wydarzenia: Bożych narodzin. Swoistym, bo ukierunkowanym na osoby i relacje między nimi. Osoby te należa do różnych światów: boskiego i ludzkiego. Utwór rozpoczyna się spleceniem tych światów przez relacje osób: B og a (świat boski) i rodzi c a (świat ludzki).

[...]

Przez przypomnienie prawd [teologicznych] ustanawia się zbliżenie światów, wywiedzione z relacji osobowych, które były efektem konkretnego, osadzonego w czasie historycznym, fragmentu dziejów zbawienia (Boże Narodzenie)".

O st row s ka, op. cit., s. 50. Podkreśl. K. O.

29 Zob. É. Souriau, Czym jest sytuacja dramatyczna? W zb.: Studia z teorii literatury. Archiwum przekładów „Pamiętnika Literackiego”. T. 2. Red. K. Bartoszyński, M. Głowiński, H. Markiewicz. Wrocław 1988, s. 272-276.

31 Zob. Ostrowska, op. cit., s. 27. 
kompozycyjny tekstu pojęty jest przez anonimowego autora antytetycznie"32), stają: \{aniołowie\} $\}^{33}$ (jako byty usytuowane pomiędzy człowiekiem a Bogiem), \{Lucyfer\} (ten wszak jest, mówiąc najkrócej, upadłym aniołem, a zarazem głównym antagonistą Boga ${ }^{34}$; konkretniej: w świecie odgrywa rolę „małpy Boga”35\}, \{poganie\} (jako przeciwieństwo współtworzą oni tożsamość religijną chrześcijan) oraz \{Żydzi\} (jeśli nie w tej samej, to w funkcji przynajmniej podobnej jak poganie ${ }^{36}$ ), a także \{potępieni chrześcijanie\} (wszak opozycja nieba - z prowadzącym doń czyśćcem i piekła warunkuje zasadność prośby o „rajski przebyt”). W porządku wertykalnym postacie te współtworzą następującą hierarchię: \{Lucyfer\} $\rightarrow$ \{potępieni chrześcijanie $\} \rightarrow\left\{\right.$ poganie $\left.^{37}\right\} \rightarrow\left\{Z \dot{y} y d z i^{38}\right\} \rightarrow$ społeczność grzeszników (tzn. modlitewny podmiot)

Krążyńska, Mika, op. cit., s. 48.

Klamrami sygnalizuję status tych „domyślnych” postaci, które chociaż werbalnie nie pojawiają się w tekście Bogurodzicy, to jednak - w moim przekonaniu - pozostają elementami koniecznymi jej kontekstualnego makrokosmosu. (Dla autorów Architektury „Bogurodzicy” podstawową zasada tekstu jest w planie formalnym „dopełnianie przez przeciwieństwa” (s. 60〉.) Innymi słowy: postacie te są takimi mocą fundamentalnej dla strukturalizmu logiki: analogicznie jak każdy element języka nie ma statusu samodzielnego, lecz swe istnienie wywodzi $z$ wielorakich opozycji, tak też aniołowie, Lucyfer, poganie, Żydzi oraz potępieni chrześcijanie będą domyślnymi postaciami koniecznymi świata ukazanego w Bogurodzicy.

W przedstawieniach znanych jako Deesis, stanowiących część ikonografii Sądu Ostatecznego, pojawiają się m.in. te zatytułowane Są Ostateczny, w nich diabeł nie tylko jest „potencjalny”, lecz niekiedy również „realny”: ikona ze szkoły nowogrodzkiej (trzecia ćwierć XV w.) - zob. R. M a zu rki e w i cz, Deesis. Idea wstawiennictwa Bogarodzicy $i$ św. Jana Chrzciciela $w$ kulturze średniowiecznej. Kraków 2002, il. 8. Inną wizualizacją teologicznej więzi Boga, Marii i diabła może być niemiecki ołtarzyk przenośny z końca w. XII - zob. Z. Obertyń ski, Wyobrażenie Trójcy Św. $w$ tzw. Modlitewniku Warneńczyka. Lwów 1932, s. 9. Centralne przedstawienie, unaoczniające dogmat o pochodzeniu Ducha Świętego „a Patre Filoque”, to Trójca Święta: wiszący na krzyżu Syn Boży, podtrzymujący Go za ramiona Bóg Ojciec, ich głowy sa jakby połączone symbolizującym Ducha Świętego gołębiem (niejako wylatującym z ust Boga i spadającym na głowę Syna - co unaocznia formułe „a Patre Filoque”; nad tym centralnym przedstawieniem zobaczymy dwa symetrycznie usytuowane półksiężyce, na jednym jest widoczna głowa kobiety z mniejszym półksiężycem na głowie (Maria?), na drugim półksiężycu - popiersie i głowa postaci $z$ ogromnymi rogami (diabeł?). Wszystkie te postacie zawierają się w okręgu, którego punktem centralnym jest symbolicznie przedstawiony Duch Święty. Zob. też D. Forstner, Świat symboliki chrześcijańskiej. Przeł. W. Zakrzewska, P. Pachciarek, R. Turzyński. Warszawa 1990, s. 101.

Zob. M. Rudwin, Diabet $w$ legendzie i literaturze. Przeł. J. Ilg. Kraków 1999, s. 143. Zob. też W. Brojer, Diabet $w$ wyobraźni średniowiecznej. Trzynastowieczne exempla kaznodziejskie. Wrocław 2003, s. 214-246, 396-442.

Tego, że także Żydzi są elementami koniecznymi makrokosmosu Bogurodzicy, pośrednio dowodzi np. Psatterz floriański z jego przedstawieniami astrologicznymi - zob. E. Śn i ézy ń s ka - S t o lo t, Tajemnice dekoracji „Psałterza floriańskiego”. Z dziejów średniowiecznej koncepcji uniwersum. Warszawa 1992, s. 75: „W zodiologii Ryby oznaczały Żydów i nowo nawróconych pogan, a więc posłużenie się tym znakiem przez królową [Jadwigę], dzięki której chrześcijaństwo dotarło do pogańskiej Litwy, wydaje się całkowicie zrozumiałe".

O wyższości religijnej pogan nad potępionymi chrześcijanami mogło rozstrzygać to, że chociaż tym pierwszym nie została dana łaska wiary, to przecież ich status religijny określała formuła „anima naturaliter christiana". Potępieni chrześcijanie otrzymaną od samego Boga łaskę wiary swoimi grzechami odrzucili, poganom zaś (przyjmijmy upraszczające uogólnienie) owa łaska bądź nie była dana, bądź zostali nią obdarzeni jedynie w ograniczonym zakresie (vide Platon, Arystoteles, stoicy). O takim usytuowaniu Żydów: ponad potępionymi chrześcijanami (a przynajmniej heretykami - o ile ci w ogóle zostaną uznani za chrześcijan) i poganami, zob. [P. S k a r g a], Upominanie do ewanjelików 
$\rightarrow$ \{zbawieni chrześcijanie $\rightarrow$ \{aniołowie $\rightarrow$ Chrzciciel $\rightarrow$ Maria $^{39} \rightarrow$ Bożyc $\rightarrow$ Bóg w Trójcy. Ten porządek wertykalny jest sprzężony z porządkiem linearnym (,przestrzen, wykreowana w odniesieniu do czasu przeszłego (historycznego), rozciaga się i obejmuje teraźniejszość" ${ }^{40}$ ): Bóg w Trójcy $\rightarrow$ \{aniołowie $\rightarrow$ \{diabeł $\rightarrow$ \{poganie\} $\rightarrow\{$ Żydzi jako naród wybrany $\} \rightarrow$ Maria i Chrzciciel $\rightarrow$ Bożyc $\rightarrow$ społeczność grzeszników. Te dwa porządki ${ }^{41}$ można unaocznić w postaci schematu (który siła rzeczy pozostanie właśnie tylko schematem - jednak przedstawiającym współdziałanie zasady następstwa i zasady równoczesności ${ }^{42}$ ):

\begin{tabular}{|c|c|}
\hline $\begin{array}{c}\text { NIEBO } \\
\text { (W TYM } \\
\text { CZYŚCIEC): }\end{array}$ & $\begin{array}{c}\text { Bóg w Trójcy } \\
\uparrow \\
\text { Bożyc } \\
\uparrow \\
\text { Maria } \\
\uparrow \\
\text { Chrzciciel } \\
\uparrow \\
\{\text { aniołowie } \\
\uparrow \\
\text { \{zbawieni\} }\end{array}$ \\
\hline ZIEMIA: & $\begin{array}{c}\text { Bóg w Trójcy } \rightarrow \text { \{aniołowie }\} \rightarrow\{\text { diabeł }\} \rightarrow\{\text { poganie }\} \rightarrow\{\text { Żydzi jako naród wybrany }\} \\
\rightarrow \text { Maria i Chrzciciel } \rightarrow \| \text { Bożyc }\|\|^{43} \rightarrow \text { społeczność grzeszników }\end{array}$ \\
\hline PIEKŁO: & $\begin{array}{c}\text { \{potępieni\} } \\
\uparrow \\
\{\text { Lucyfer i pozostałe upadłe anioły\} }\end{array}$ \\
\hline
\end{tabular}

i do wszystkich spotem niekatolików, iż o skażenie zborów krakowskich gniewać się i nic nowego $i$ burzliwego zaczynać nie maja. Kraków 1592. W: M. Ko rolko, Klejnot swobodnego sumienia. Polemika wokót konfederacji warszawskiej w latach 1573-1656. Warszawa 1974, s. 190; zob. też s. 196.

39 W tradycji wschodniej Maria, a niekiedy również Jan Chrzciciel zajmują miejsce ponad aniołami; Deesis unaocznia ich bezpośrednią bliskość wobec „Bożyca”; aniołowie w hierarchii Deesis stoją za nimi.

40 Krążyńska, Mika, op. cit., s. 55.

41 Zob. ibidem, s. 56: „W Bogurodzicy kreuje się metafizyczną przestrzeń, tworząc ją jakby na nowo dla modlitwy. Krok za krokiem ustanawia się relacje przypominające boską historię $\mathrm{z}$ początków nowej ery. Równolegle do tego rozwija się drugi plan czasowy, w którym istnieje modlitwa. Plan otwarty w czasie, włączający ludzi w świętą historię. Dopóki jednak nie zostanie wykreowana pelna przestrzeń metafizyczna, umożliwiająca modlitwę, nie czas na konkretne prośby".

Zob. E. S t a nki ew i c z, Poetyka i strukturalna lingwistyka. W: Poetyka i sztuka słowa, s. 52-53 (przeł. P. W a w r zy s z k o): „Zasada równoczesności powiązana z zasadą następstwa czyni z przekazu poetyckiego zintegrowaną strukturę, w której każdy element jest postrzegany jako autonomiczna część sekwencji lub też jako część całości. [...] Jednak tym, co czyni wszelką poezję sztuką "trudnego czytania", jest fakt, że zasada następstwa jest na każdym kroku komplikowana i jak gdyby powstrzymywana przez zasadę równoczesności, która skłania uwagę ku strukturze jako całości”. Zob. też s. 75-76.

43 Dwie pionowe kreski, dwukrotnie niejako „wycinające” Bożyca z dziejów świata, wyrażają to, że historyczny czas między Bożym Narodzeniem a Zmartwychwstaniem charakteryzuje się wyjątkowym statusem - zob. A. H. Armstrong, R. A. Marku s, Wiara chrześcijańska a filozofia grecka. Przeł. H. B e d n a r e k. Warszawa 1964, s. 154-156: „Wtargnięcie Boga do historii przez Wcielenie Syna jest specyficznie chrześcijańska wiara. [... Czas w ujęciu chrześcijańskim jest pojmowany ntip.pichlorg. pl 
Trójpoziomowy schemat wyraża zawarte w nim dwie opozycje przestrzeni ${ }^{44}$, tj. między warstwą przedśmiertną („tu i teraz” społeczności tworzącej modlitewny podmiot) oraz warstwą pośmiertną („tam i wiecznie” - z jej rozdwojeniem na zaświaty niebiańskie i piekielne; prowadzacy do nieba czyściec pozostaje wariantem nieba: „tam i do czasu”). Niejako na marginesie - piekło tym bardziej będzie elementem koniecznym struktury czasoprzestrzeni Bogurodzicy, ponieważ średniowieczny obraz świata był... diablocentryczny ${ }^{45}$.

Nieprzypadkowo tylko na poziomie ziemskiej doczesności strzałkami została zaznaczona procesualność dziejów zwieńczonych modlitewnym „tu i teraz”, gdyż obydwa zaświaty charakteryzują się tym, że czas ludzki tak w niebie (z nim: także w czyśćcu), jak też w piekle zostaje jakby zawieszony, unieważniony czy okazuje się wręcz niedorzeczny:

Taki jest punkt dojścia relacji przestrzenno-czasowych subtelnie przywoływanych w utworze: od czasu konkretnego, określonego (komentarz do Bożych narodzin) i związanej z nimi przestrzeni, opartej o działające osoby i relacje między nimi, przez mistyczne, eucharystyczne przeniesienie tejże przestrzeni w modlitewną teraźniejszość, po wybiegnięcie w natchnionej modlitwie w przyszłość, do rajskiej przestrzeni, gdzie czas przestanie być ważny $[\ldots]^{46}$.

Te zdania unaoczniaja, jak fundamentalnie twierdzenia teologiczne moga determinować strukturę czasoprzestrzeni. Ona zaś staje się istotną (chociaż nie jedyna) materią obrazowania poetyckiego.

Autorzy Architektury „Bogurodzicy” swój zamiar badawczy przedstawili następująco:

Stawiane najczęściej w literaturze przedmiotu pytania o przynależność kulturową, autorstwo, a zwłaszcza o czas powstania utworu kierowały uwagę badaczy w stronę problemów i analiz szczegółowych. Nie znaczy to, że nie zauważano artyzmu Bogurodzicy. Przeciwnie, słowa zachwytu pojawiały się bardzo często, wskazywano - i słusznie - takie cechy, jak dwudzielność, antytetyczność i paralelizm jako zasady konstrukcyjne utworu. Jest to jednak - naszym zdaniem - zbyt mało. Trzeba jeszcze zwrócić uwagę na niezwykłą spójność utworu oraz ukazać, jak rozdzielne płaszczyzny wzajemnie się dopełniają, i to na różnych poziomach organizacji tekstu ${ }^{47}$.

Trójpoziomowa struktura czasoprzestrzeni Bogurodzicy zawiera dwie pary przeciwstawień spacjalnych $^{48}$ : niebo (z prowadzącym doń czyśćcem) - ziemia; zie-

jako ruch prostoliniowy, czy, bardziej dokładnie mówiąc, jako ruch po przełamanej w pewnym miejscu linii prostej, czy po dwóch liniach, jak to wyraża nasze [tj. chrześcijańskie - K. O.] liczenie czasu przed Chrystusem i po Chrystusie".

Zarówno anonimowy malarz z w. XIV wieku, jak też J. van Eyck (ok. 1440 r.) w swoich przedstawieniach Sądu Ostatecznego unaocznili pionową oś, będącą niejako drogą łączącą trzy teologiczne poziomy świata i zaświatów: piekło, ziemię i niebo. Zob. A. K. Turner, Historia piekła. Przeł. J. J a rniewicz. Gdańsk 1996, il. 7-8.

45 Zob. N. M. Wild i e rs, Obraz świata a teologia. Od średniowiecza do dzisiaj. Przeł. J. D o k tó r. Warszawa 1985, s. 98: „Co bowiem [w systemie geocentrycznym] znajdowało się w centrum ziemi? Piekło! A co znajdujemy w środku piekła? Tron Lucyfera! Wygląda to wręcz na bluźnierstwo: świat stał się, używając słów Lovejoya, światem "diablocentrycznym"... Nie Bóg, lecz diabeł zajął honorowe miejsce we wszechświecie".

$46 \quad$ Krążyńska, Mika, op. cit., s. 61.

47 Ibidem, s. 51.

48 Zob. T. Mi ch hałow s ka, Kochanowskiego poetyka przestrzeni. W: Poetyka i poezja. Studia i szkice staropolskie. Warszawa 1982, s. 276. 
mia - piekło. Granice oddzielające te trzy światy (czyśćca jednak nie należy traktować jako czegoś równorzędnego niebu czy piekłu) mają cztery oddzielne jakby przejścia graniczne przeznaczone dla: Boga jako Stwórcy (zarazem transcendentnego oraz immanentnego w dziele stworzenia świata i człowieka), Jezusa Chrystusa (z Jego Wcieleniem i Zmartwychwstaniem, Wniebowstapieniem i zstapieniem do piekieł), Marii (Niepokalanie Poczętej i Wniebowziętej), ludzi pośmiertnie zbawionych (tu także dusz pokutujących w czyśćcu) lub potępionych.

W kontekście polskiej średniowiecznej poezji religijnej nieprzewyższona zwięzłość wysłowienia Bogurodzicy wyraża się także w tym, że zamiast choćby tylko najoszczędniejszego opisu wertykalnie troistej czasoprzestrzeni werbalizowane są jedynie jej (można powiedzieć) sygnalne znaki. Te okazują się paradoksalne: wbrew swej werbalnej małomówności (trudno wszak twierdzić, że przedstawienia słowne ewokują wyobrażenia plastyczne) stają się wręcz najwymowniejsze, jako że najintensywniej rozjaśnione osobami Boga w Trójcy, Marii i Jana Chrzciciela. Trójpoziomowa struktura czasoprzestrzeni, współtworzona przez doczesną ziemię i przyszłe miejsca zbawienia lub potępienia, pełnię swego znaczenia zyskuje nie dzięki jakiejkolwiek teologicznej oryginalności (tej próżno tu szukać ${ }^{49}$ - wyłączywszy skrajną kondensację wysłowienia), lecz dlatego, że jest dziełem takiej sztuki poetyckiej, która po kilku wiekach i w zupełnie innym kontekście mogłaby zostać określona jako „maksimum treści, minimum słów”.

Średniowieczny autor Bogurodzicy najzwięźlej unaocznił to, co będzie jedną z pierwszorzędnych materii tzw. poezji metafizycznej: rozdarcie człowieka między pobożnością a grzesznością. Światem totalnie religijnym rządzi zasada pars pro toto:

O co nasi przodkowie modlili się zatem w Bogurodzicy? Do Maryi o owoce Wcielenia („spuści nam”); przez Jana Chrzciciela o owoce Objawienia („napełń myśli”); do Chrystusa - za wstawiennictwem obojga pośredników - o dobra najprostsze i najcenniejsze zarazem: „na świecie zbożny pobyt, po żywocie rajski przebyt".

[...] nieznany twórca Bogurodzicy, bez wątpienia znakomity teolog, zawarł w pieśni liczącej niespełna pół setki słów elementarne prawdy chrześcijańskiej wiary: o Wcieleniu Chrystusa, o Boskim Macierzyństwie Maryi i Jej wieczystym dziewictwie, o Jej przebywaniu w chwale niebiańskiej, o skuteczności pośrednictwa świętych, o ludzkim bytowaniu w perspektywie wieczności. Nie przypadkiem zatem przez stulecia uważano Bogurodzice za „katechizm ojców” [... $]^{50}$.

Trójpoziomowa struktura współistnieje także z inną konstrukcją, tzn. z paralelizmem między dwoma światami:

\begin{tabular}{|ll|}
\hline Nadprzyrodzony: & $\begin{array}{l}\text { Przedwieczny Bóg } \rightarrow \text { Zwiastowanie i Wcielenie } \rightarrow \text { Wniebowstąpienie } \\
\text { i Wniebowzięcie }\end{array}$ \\
\hline Przyrodzony: & $\begin{array}{l}\text { poganie } \rightarrow \text { Żydzi } \rightarrow \text { chrześcijanie (drogami życia podążający ku zbawieniu// } \\
\text { potępieniu) }\end{array}$ \\
\hline
\end{tabular}

Dwie przedstawione tabele współtworzą zwerbalizowany w Bogurodzicy obraz

Zob. C. S. Lew is, Odrzucony obraz. Wprowadzenie do literatury średniowiecznej i renesansowej. Przeł. W. O strowski. Warszawa 1986, passim.

50 R. Mazurkiewicz, Siedem pieczęci „Bogurodzicy”. Na stronie: http://staropolska.pl/sredniowiecze/poezja_religijna/Bogurodzica/siedem/html (data dostępu: 1 XI 2014). 
struktury czasoprzestrzeni. Oczywiście, można spierać się, czy jednak już w swej istocie schematyczne takie lub inne tabele nie stają się formą interpretacyjnej znieczulicy wobec tekstu tak nieprzeciętnie artystycznego. Paradoksalnie: $\mathrm{z}$ jednej strony, wyjątkowa kondensacja słów naszej pieśni narodowej, z drugiej zaś - wariantywność relacji między nimi (uwarunkowana odmiennymi zapisami przekazu kcyńskiego). Zarazem jeśli „Określony najogólniej strukturalizm jest czymś w rodzaju czujności nastawionej na chwytanie współzależności i współdziałania części w ramach pewnej całości [...]"51, to obydwie tabele można potraktować jako wyraz owej czujności.

Znacząco odmienne zapisy graficzne przekazu kcyńskiego może nawet nakazuja, by powiedzieć: nie ma jednego przekazu kcyńskiego - w istocie tekstowej rzeczy jest ich tyle, ile zapisów $z$ ich wariantami sztuki wersyfikacji, w której to sztuce anonimowy autor średniowieczny i edytorzy jego tekstu współtworzą relację sprzężenia zwrotnego. Jeśli przedstawione tu schematyczne tabele będą postrzegane jako rozerwanie związków między słowami wiersza, to za takim odejściem od porządku linearnego słów w kolejnych wersach Bogurodzicy przemawiaja wielorakie stroficzne warianty zapisu przekazu kcyńskiego. One sprawiają, że nawet pojedyncze słowa współtworzą różnorodne kombinacje, toteż o „wyższej i nierozerwalnej całości”" 52 tekstu Bogurodzicy zarazem można i nie można mówić.

\section{Obraz poetycki ${ }^{53}$}

Otóż obrazy mentalne wywoływane u czytelników przez wybitne teksty literackie przyćmiewają niekiedy bezpośrednie bodźce zmysłowe.

[...]

Przez wizualizację [...] można rozumieć przedstawianie - w sposób wzrokowo dostępny innym ludziom - wszelkich treści wewnętrznych, zarówno sensorycznych, jak i abstrakcyjnych. [Zdzisław Łapiński] ${ }^{54}$

51 J. Star obin s ki, Uwagio strukturalizmie. Przeł. E. Bi eń k ow s ka. „Pamiętnik Literacki” 1974, z. 3, s. 272 .

52 Zob. E. Stankiewicz, Poetyka i sztuka słowa. W: Poetyka i sztuka słowa, s. $93-94$ (przeł. J. Żukower-Narbuntowicz, T. Sławek):

„Równoczesność nie przeczy następstwu, a wręcz przeciwnie - wzmacnia je i ostrzej uwydatnia. [...]

[...] Najwyraźniej ów ruch naprzód i wstecz odczuwany jest w wierszu, gdzie każdy wers wiedzie nieuchronnie ku następnemu, który z kolei odwołuje się do swego poprzednika, współtworząc z nim wyższą i nierozerwalną całość”.

53 W tej części wykorzystuję wcześniejszą swoją publikację: K. O b r e m s k i, Obraz Boga w polskiej liryce religijnej XVII wieku. Toruń 1990, s. 9-20.

54 Z. Ła pińs ki, Widziane, wyobrażone, pomyślane. „Teksty Drugie” 2009, nr 1/2, s. 47-48. Zob. też E. Balcerzan, Widzialne i niewidzialne $w$ sztuce słowa. Jw., s. 33:

„Wizualizacje rozumiem jako zdarzenie komunikacyjne, w którym jego uczestnik czuje się świadkiem przemiany niewidzialnego w widzialne. [...]

Obiektem literackiej wizualizacji jest znaczenie, zarówno pojedyncze, leksykalne, jak i konstrukcyjne, wyczytywane $z$ chwytów artystycznych, transmitowane również poprzez złożone, wewnątrztekstowe kombinacje znaczeniowe. Wszelkie postaci literackiego znaczenia konstytuują w dziele jego warstwę niewidzialną, a zatem spełniaja pierwsze kryterium obiektu wizualizacji”. 
Niepodobna choćby tylko wskazać sporne czy też dyskusyjne punkty problematyki obrazu poetyckiego ${ }^{55}$ (tu pojmowanego samoistnie, tj. nie jako wypowiedź o znaczeniu metaforycznym). Aby unaocznić zakres „uczonej niewiedzy” jego badaczy, wyłącznie na zasadzie pars pro toto przywołam zdanie Barbary Otwinowskiej: „Termin »o b r a z“ jest jednym $z$ najbardziej wieloznacznych i niejasnych terminów jeszcze i dzisiejszej teorii literatury, która nie rezygnując $z$ jego znaczeń dawnych, dodała doń nowe, własne" ${ }^{56}$. W kontekście tegoż twierdzenia (sformułowanego wszak w materii nieporównywalnie głębiej i pełniej poznanej niż średniowieczna teoria literatury) zakres „uczonej niewiedzy”, w jakiej mimo wszystko wciąż pozostaje i, być może, do końca będzie pogrążona Bogurodzica, nakazuje przywołać jeszcze jedno zdanie - biblisty:

Niekiedy przy niektórych wyrażeniach i tekstach trudno jest określić, czy mamy do czynienia z metafora, czy też nie. Z naszego [tj. współczesnego - K. O.] punktu widzenia skłonni bylibyśmy prawdopodobnie powiedzieć, że tak, ale jest wątpliwe, czy ludzie i autorzy biblijni podobnie odczuwali i widzieli te słowa i wyrażenia. Mogli pojmować i odczuwać swe określenia jako ukazujące wprost i najściślej tę rzeczywistość, o której mówili. Ten fakt powinien chyba być sygnałem, że przy rozpatrywaniu metafory nie powinniśmy się kierować tylko naszym spojrzeniem i kategoriami, ale również brać pod uwagę spojrzenie i odczucia tych, którzy wypowiadali analizowane przez nas słowa ${ }^{57}$.

Poznawczo podobnie nam daleko do czasów Biblii, jak też do Polski Piastów czy nawet Władysława Jagiełły ${ }^{58}$. Nie potrafimy bez wątpliwości odpowiedzieć na pytanie o to, czy słowa Bogurodzicy były rozumiane przenośnie, tym bardziej że metafora pozostałaby problemem głównie poetyki immanentnej, a jedynie umiarkowanie sformułowanej: w średniowiecznej teorii literatury w Polsce pojawiała się głównie w kontekście alegorii i teorii „trzech stylów”59. Ponadto: niepodobna definitywnie rozstrzygnąć kwestii przenośnych znaczeń słów Bogurodzicy także z tego powodu, jakim jest sam język chrześcijańskiej teologii dogmatycznej - w nim metaforyczność to niejako przyrodzona właściwość każdej wypowiedzi ${ }^{60}$ (także w za-

Jedną z ciekawszych publikacji wciąż pozostaje praca W. A. Zari e cki e go Obraz jako informacja (Przeł. L. S u ch a n ek. „Pamiętnik Literacki” 1969, z. 1).

56 B. O tw in ow s ka, „Homo metaphoricus” $w$ teorii twórczości XVII $w$. W zb.: Studia o metaforze. I. Red. E. Sarnowska-Temeriusz. Wrocław 1980, s. 51. Podkreśl. K. O. Podobnie pisze M. R. May e now a (Poetyka teoretyczna. Zagadnienia języka. Wrocław 1979, s. 160): „irytująco niejasny wyraz-termin "obraz" może uzyskać bardziej określony sens przy użyciu terminologii semiotycznej".

57 J. Frankowski, Metafora $w$ „Biblii”. W zb.: Studia o metaforze. II. Red. M. Głowiński, A. Okopień-Sławińska. Wrocław 1983, s. 173.

O tak późnym datowaniu powstania Bogurodzicy zob. J. Krzyża n ow s ki: op. cit., s. 34; Dzieje literatury polskiej od początków do czasów najnowszych. Warszawa 1970, s. 20. Takie odosobnione wśród polskich badaczy stanowisko zostało potwierdzone przez austriackiego muzykologa, R. Flotzing e ra (Jeszcze o kwestii „Bogurodzicy”. Przeł. A. G o r zk ow s ki. „Pamiętnik Literacki” 2005, z. 2, s. 10).

59 Zob. Mich ałow s ka, Średniowieczna teoria literatury $w$ Polsce, passim.

60 Zob. Frankowski, op. cit., s. 159: „Najbardziej podstawową przyczyną występowania metafory w Biblii, przyczyną związana z ostatecznym charakterem tej ksiegi, jest to, że Biblia mówi o Bogu, o nadprzyrodzoności, a więc o rzeczywistości transcendentnej, czyli przekraczającej [...] kategorie naszych pojęć i myśli. W takiej sytuacji, rzecz oczywista, kończy się możliwość operowania terminami dosłownymi, a pozostaje 
chodnim chrześcijaństwie teologia apofatyczna wiedzie swój żywot, co prawda, od wieków przesłaniany teologia pozytywną, ale nigdy nie zakryty definitywnie - ostatecznie nawet neoarystotelik św. Tomasz nie taił, że Bóg przewyższa poznanie istotowe poprzez rodzaj i gatunek: „Deus non est in genere”).

W kontekście problematyki obrazu poetyckiego Bogurodzica okazuje się tekstem stwarzającym dwojakie trudności:

- charakteryzuje ja znikome obrazowanie poetyckie, pojmowane jako sztuka kreowania plastycznych przedstawien słownych;

- z powodu zwięzłości wysłowienia pieśń jest skrajnie zwarta, wręcz skondensowana: w pierwszej strofie liczebnie przeważają nazwy imienne, jakże stosunkowo niewiele w niej orzeczeń i przydawek; w drugiej ta liczebna przewaga imion staje się mniejsza; autora Bogurodzicy jednak trudno postrzegać jako poetę respektującego to twierdzenie klasycznej teorii retorycznej: „W opowiedzeniu [zwięzłym] należy trzymać się drogi pośredniej, mówiąc tyle, ile jest niezbędne, ale i tyle, by wystarczyło" (Kwintylian) ${ }^{61}$.

W kontekście tych dwojakich trudności mniejsza nawet o etymologię trójwymiarowego „obrazu” 62 .

Mówiąc nieco prowokacyjnie: Bogurodzica - dzieło sztuki obrazowania - może jawić się jako zaprzeczenie plastyczności przedstawień słownych, wszak wolno ją czytać niczym sekwencje jedynie punktowo przywoływanych postaci Boskich i ludzkich (ich statusy oraz działania zostają wyłącznie zasygnalizowane; pełniejsze wyobrażenie o tym, co w sposób skrajnie syntetyczny tekst wyraża, jest uwarunkowane dopełnieniem go wiedzą teologiczną, a więc istotnym elementem makrokosmosu tekstu). Innymi słowy: Bogurodzica to pieśń z pewnością bardzo rozbudowana teologicznie, jednak dla wyobraźni pobudzanej szczególnie wzrokiem jej tekst pozostanie raczej „wywoływaczem” obrazu poetyckiego niż nim samym. Czyż w takim stanie znikomo obrazowej rzeczy ${ }^{63} \mathrm{w}$ ogóle można mówić o poetyckim obrazowaniu?

Julian Krzyżanowski - wyróżniwszy trzy poziomy obrazu: szczegółowy obraz

jedynie możliwość - by w ogóle mówić na temat tego, co transcendentne - podjęcia analogii, obrazu, metafory". O całkowitej porażce myśli, która zamierzała Boski majestat oddać słowami zob. J. H u izing a, Jesień średniowiecza. Przeł. T. Brz o s tow ski. Warszawa 1974, s. 260.

61 Cyt. za: H. La u s b e rg, Retoryka literacka. Podstawy wiedzy o literaturze. Przekł., oprac., wstęp A. Gorzkowski. Bydgoszcz 2002, s. 182.

62 W średniowiecznej i jeszcze w XVI-wiecznej polszczyźnie słowo „obraz” - jak pisze J. Krzyżanow s k i (Sztuka słowa. Rzecz o zjawiskach literackich. Warszawa 1972, s. 102) - nie oznaczało malowidła, ale posag, statuę, te bowiem „zawdzięczały swe powstanie nie pociagnięciom pędzla, lecz "razom", tj. ciosom dłuta, gdy ciosy zadawane człowiekowi innym narzędziem wywoływały obrazę, etymologicznie rodzoną siostrę obrazu".

63 Zob. Łotman, op. cit., s. 310-311: „Szczególny, właściwy człowiekowi charakter wzrokowego odbioru świata, którego wynikiem jest to, że denotatami znaków słownych dla ludzi w większości przypadków są pewne przestrzenne, postrzegalne obiekty, prowadzi do określonego odbioru modeli werbalnych. Zasada ikoniczna, naoczność są im też w pewnej mierze właściwe. Można wykonać pewien eksperyment myślowy: wyobraźmy sobie jakieś skrajnie uogólnione pojęcie całkowicie abstrahujące od jakichkolwiek cech konkretnych, jakieś ws zystko i spróbujmy określić dla siebie jego cechy. Nietrudno przekonać się, że cechy te dla większości ludzi będą miały charakter przestrzenny $[\ldots] "$. 
słowny, obraz poetycki, obraz artystyczny nadrzędny - wskazał swoistość obrazowania w tekstach lirycznych:

Gdy dramat lub dzieło epickie obejmuje szereg obrazów odpowiednio według jakichś zasad ułożonych i zhierarchizowanych, w poemacie lirycznym sprawa jest częstokroć bardzo prosta; wyrazić ją można $\mathrm{w}$ równaniu: obraz poetycki $=$ utwór $[\ldots]^{64}$.

Tak właśnie rzecz się ma z Bogurodzica: wbrew jakże skromnej liczbie słów, które nie współtworzą wypowiedzi wyróżniającej się plastycznością i sensualną konkretnością ewokowanych nimi wyobrażeń, pieśń narodowa okazuje się obrazem poetyckim za sprawą znamiennego dla tekstów lirycznych spłaszczenia poziomów - szczegółowy obraz słowny, obraz poetycki i obraz artystyczny nadrzędny współkreuja jednię, w której dwa niższe poziomy obrazowania jakby zanikaja, niejako wciagnięte czy też pochłonięte przez finalny poziom najwyższy, tj. przez obraz artystyczny nadrzędny. Dlatego o Bogurodzicy jako o pieśni zawierającej obraz poetycki można mówić wbrew temu, że jej liczbowo jakże skromne słowa nie wyróżniają się plastycznością i konkretnością ewokowanych wyobrażeń.

Zarazem obraz poetycki posiada także inne komponenty niż te wyłącznie naoczne czy wielorako sensualne. Np. Cecil Day Lewis zdefiniował go jako „mniej lub bardziej zmysłowe wyobrażenie słowne"65, w którym przedstawienia wzrokowe pozostają najbardziej pospolitym rodzajem obrazu: naoczność może zachować wielkość jedynie minimalną, może też zostać tak mocno przesłonięta spostrzeżeniami zmysłów innych niż wzrok, że będzie bliska zera, wszakże choćby minimalna cząstka wizualności to element konstytutywny obrazu poetyckiego. Przy takim jego pojmowaniu wolno powiedzieć, że Bogurodzica zawiera go, gdyż „wyobrażenia słowne" w poważnym zakresie pozostają zmysłowe: co prawda Trójca Święta, Bożyc, Maria czy Chrzciciel to słowa-znaki o sensach naocznych, konstytuowanych może nawet nie tyle przez teologię, ile przez kazania czy sztukę sakralną (o tekstach apokryficznych nie wspominając), ale jednak społeczność grzeszników jako podmiot modlitewnych próśb dla niej samej była przecież jak najbardziej cieleśnie konkretna i tym samym postrzegana zmysłami oraz tworzona przez emocje - w tym przez przerażenie perspektywą mąk piekielnych (vide dawna pedagogika strachu). Za pewnik można przyjąc, że grzesznicy, prosząc o „rajski przebyt”, gdzieś przed oczami mieli choćby słabo zarysowaną wizję rajskiej szczęśliwości, jak też o ileż wyrazistszy obraz tego, co wiecznie potępionych czeka w piekle (te dwa zaświaty poniekąd były połączone relacją sprzężenia zwrotnego). Ta cielesność społeczności grzeszników jako somatyczne podłoże unaocznienia poetyckiego może być wiązana $\mathrm{z}$ tym, co Kleiner pisał w pracy Rola pamięci $w$ recepcji dzieła literackiego $i w$ jego strukturze ${ }^{66}$. Obrazotwórczą funkcję Bogurodzicy prymarnie determinowały statusy Boskich osób, tzn. Bóg w Trójcy, Maria i Chrzciciel współtworzyli najświętszy

J. Krzyża n ow s ki, Nauka o literaturze. Wrocław 1966, s. 188.

C. D. Lew i s, The Poetic Image. London 1949, s. 18-19: „każdy obraz - nawet najbardziej emocjonalny czy intelektualny - zawiera w sobie ślad zmysłowości [...]”.

Zob. H. Marki ew i c z, Wymiary dzieła literackiego. Kraków 1984, s. 29-30: „poprzestańmy na przypomnieniu uwagi Juliusza Kleinera, akceptującego zresztą istotność "poetyckiego unaocznienia»: podobnie jak obrazy zapamiętane, tak i wyobrażenia wywołane tekstem literackim są twora- 
kres ludzkiej wyobraźni. Samych zaś grzeszników charakteryzowała najwyższa intensywność zaangażowania emocjonalnego, gdyż materią modlitwy i jej celem stała się wartość nieprzewyższona: „rajski przebyt”.

John Middleton Murry opowiedział się za tym, aby „stanowczo pozbyć się sugestii, że obraz [poetycki] jest wyłącznie czy choćby głównie wzrokowy" - ten bowiem może być wzrokowy, słuchowy albo też „całkowicie psychiczny”67. Nawet jeśli przyjmiemy, iż sensualność wyobrażeń ewokowanych słowami Bogurodzicy można zakwestionować jako historycznie tylko hipotetyczną, to raczej niepodobna zaprzeczyć temu, że w Polsce wieków średnich tak sama wiara chrześcijańska, jak też szczególnie kult maryjny charakteryzowały się silną emocjonalnością. Jakkolwiek wielorakie byłyby te emocje religijne, współtworzyły obraz poetycki - pojmowany jako „całkowicie psychiczne” przedstawienie słowne. Emocje doprawdy skrajne, gdyż sprzężone z życiem podmiotu modlitewnego: tak doczesnym („zbożny pobyt”), jak wiecznym (,rajski przebyt”). Właśnie także jako forma błagalna Bogurodzica staje się takim obrazem poetyckim, w którym akt modlitwy współkreuje jednię $z$ trudną do odtworzenia plastycznością przedstawień słownych (Deesis?!). Taż plastyczność byłaby „wydarzeniem pojęciowym w szczególny sposób powiązanym $z$ wrażeniem” ${ }^{68}$ ? Zarazem niepodobna mówić $z$ pewnością o pojedynczym "wydarzeniu pojęciowym” i o jednym powiązanym $z$ nim „wrażeniu” - tak w samej epoce średniowiecza (świątynia i liturgiczne funkcje pieśni ${ }^{69}$ versus pola Grunwaldu), jak współcześnie (czym innym pozostanie Bogurodzica śpiewana w trakcie uroczystości religijno-państwowych, czym innym jako poznawcze wyzwanie np. dla literaturoznawców lub muzykologów). Równocześnie pieśń stawała się i wciąż staje się obrazem poetyckim za sprawa śpiewu, którego siła tworzenia plastycznych przedstawień słownych była i jest wzmacniana jej religijnym statusem - wszak jest śpiewana nieprzypadkowo $^{70}$.

Paradoksalnie: „Bogurodzica jest trudna. Można ją umieć na pamięć wspak i w poprzek, a mimo to wciąż czegoś w niej nie dostrzegać, co potem nagle okaże się zupełnie proste"71. Ta pieśń ojczysta wciąż nakazuje przekraczać horyzonty jej poznawania. $\mathrm{W}$ tym jako materia analizy wizualizacji.

mi selektywnymi, złożonymi z niewielkiej ilości rysów, dzięki temu intensywnych, a zarazem samowystarczalnych i nie wymagających uzupełnień".

Cyt. za: R. W elle k, A. W arr en, Teoria literatury. Przeł. I. Si e r a d zki. Przekł. pod red. i z posł.

M. Żurows ki e go. Warszawa 1976, s. 247.

Słowa I. A. Rich ard sa. Cyt. jw., s. 246.

69 Zob. Flotzinger, op. cit., s. 8:

„[...] interpretację Bogurodzicy jako tropu kyrialnego należy ostatecznie odłożyć ad acta. [...]

Natomiast określenie Bogurodzicy terminem "pieśń" jest najzupełniej trafne, jakkolwiek nie nazbyt precyzyjne. Nie ma wątpliwości, że wykonywano ją na podobieństwo chorału. Wątpliwości można natomiast żywić co do tego, czy przeznaczona była pierwotnie do celów liturgicznych, a w jeszcze większym stopniu: czy przeznaczona była dla "ludu« lub narodu w ogóle".

70 Zob. R. Mazurkiewicz, Z. Wanicowa, Dlaczego „Bogurodzice” śpiewano $w$ liturgicznym okresie Bożego Narodzenia? „Pamiętnik Literacki” 2005, z. 2. - J.-P. H a s h old, „Dlaczego pod Grunwaldem śpiewano "Bogurodzicę"?", czyli duchowa rywalizacja między Krzyżakami a Polakami. Przeł. J. Le s zek. Jw.

71 Ostrowska, op. cit., s. 7. 


\section{Abstract \\ KRZYSZTOF OBREMSKI Nicolaus Copernicus University, Toruń \\ "MOTHER OF GOD”: SPATIOTEMPORAL STRUCTURE AND POETIC PICTURE}

The article is devoted to two problems, namely spatiotemporal structure and poetic picture of Bogurodzica. "Polymorphism" ("variantivity") of the Kcynia account of the piece imposes the basic choice to be made: either to accept one of five records made by medievalists as a verbal basis of the text's spatiotemporal structure recognition or to go above the verse reconstructions and have a general view on all five records. The second option seems more pertinent. Speaking somewhat provocatively, Bogurodzica a work of art of imagery - appears to be a contradiction of verbal presentation plasticity since it can be read as a sequence of spotlit recollection of human and divine figures (their statuses and actions remain merely signalled; a more full vision of what the text in a radically synthetic expresses is conditioned by theological knowledge completion - a crucial element of the text's macrocosm). 